Prepared in cooperation with Clean Water Services

\title{
Organic Matters
}

Investigating the Sources, Transport, and Fate of Organic Matter in Fanno Creek, Oregon

The term organic matter refers to the remnants of all living material. This can include fallen leaves, yard waste, animal waste, downed timber, or the remains of any other plant and animal life. Organic matter is abundant both on land and in water. Investigating organic matter is necessary for understanding the fate and transport of carbon (a major constituent of organic matter).

Organic matter is necessary for maintaining a healthy ecosystem. It participates in a wide range of ecological functions, such as supplying food to the microbes that are part of the foundation of the food chain. Organic matter also plays a role in many other natural functions, including the binding and transport of some trace metals and controlling how light is absorbed in the water column. Organic matter in a stream can be found in many places, such as in the leaves that have fallen from a tree (termed "leaf litter"), in algae floating in the stream or attached to rocks, as part of the soil, or even suspended or dissolved in the water.

The U.S. Geological Survey (USGS), in cooperation with Clean Water Services, recently completed an investigation into the sources, transport, and fate of organic matter in the Fanno Creek watershed. The information provided by this investigation will help resource managers to implement strategies aimed at decreasing the excess supply of organic matter that contributes to low dissolved-oxygen levels in Fanno Creek and downstream in the Tualatin River during summer. This fact sheet summarizes the findings of the investigation.

A. 30-day mean dissolved oxygen, no credit for supersaturation

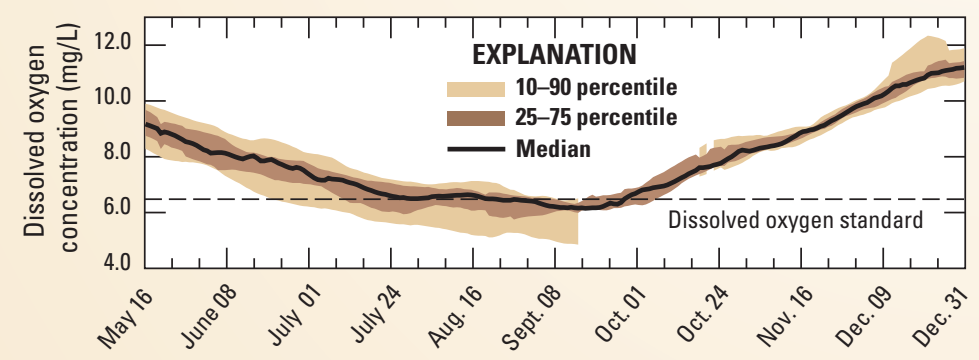

B. 7-day mean dissolved oxygen, no credit for supersaturation

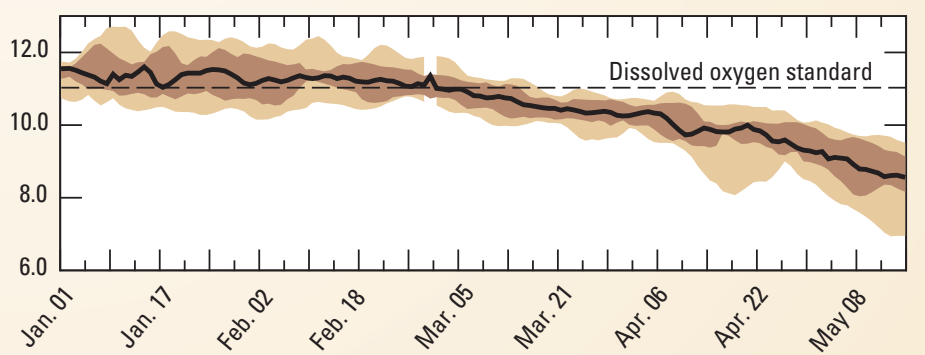

Figure 2. Dissolved oxygen (DO) concentration in Fanno Creek between 2003 and 2014. The DO standard line indicates two of the minimum thresholds to protect fish at different times in their life: $(A) 6.5 \mathrm{mg} / \mathrm{L}-30$-day average of daily mean $\mathrm{DO}$ (minimum criterion for rearing and migration period of May 16 to December 31 ) and $(B) 11 \mathrm{mg} / \mathrm{L}-7$-day average daily mean DO (minimum criterion for spawning period of January 1 to May 15). 


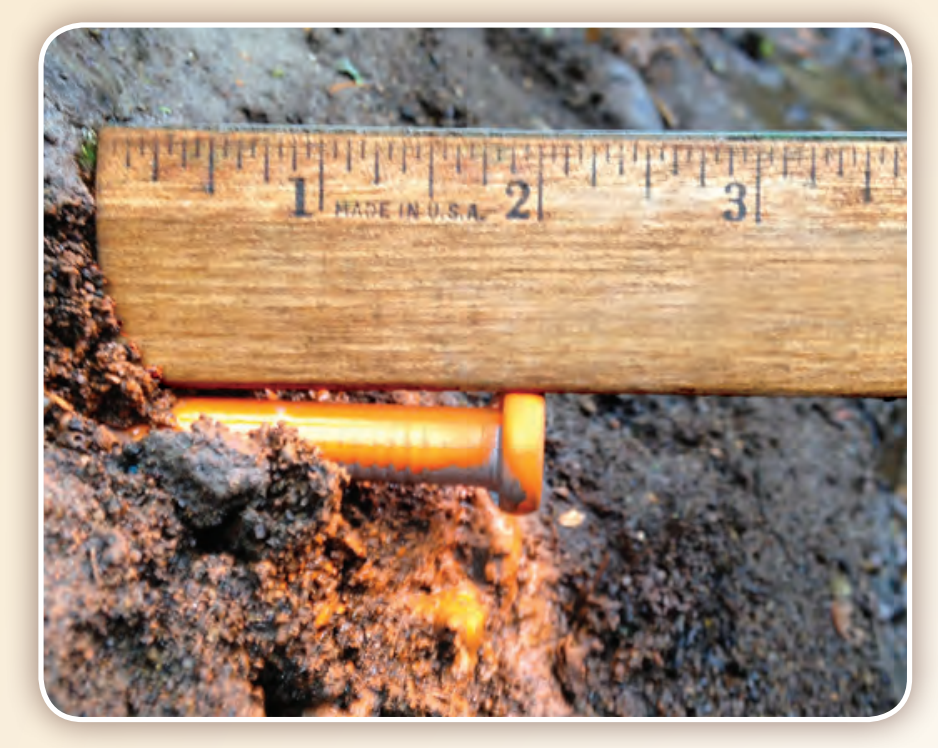

Sediment erosion was observed using metal stakes hammered into the streambanks and measured after high flow events.

by the Oregon Department of Environmental Quality and require active management in order to improve dissolvedoxygen conditions and meet State standards. The standards vary seasonally and are based on whether fish are rearing or spawning (fig. 2). For Fanno Creek, the primary sources of organic matter are terrestrial (land based), such as leaf litter and soils, rather than aquatic, such as algae. So, how much terrestrial organic matter is available along the stream? To find the answer, USGS scientists began by measuring the amount of leaf litter, or foliage, available.

\section{Organic matter in Fanno Creek comes mostly from terrestrial sources, such as leaf litter.}

\section{Leaf Litter (Foliage) Biomass}

To estimate how much leafy material exists along Fanno Creek, USGS scientists used a combination of field measurements and remotely sensed data to calculate the foliage biomass, or the total dry weight of all leaf material (fig. 3). The annual leaf litter biomass was determined for two areas: (1) all foliage across the entire floodplain, and (2) only foliage overhanging the stream. Based on this analysis, an estimated 990 metric tons ( $t$ ) of organic matter is produced annually above the Fanno Creek floodplain, with about 140 t present directly over the channel. The amount of leaf material that falls along the floodplain varies depending on the size and age of the trees, and the density of the tree canopy. Because forest-dominant reaches along Fanno Creek contain more mature deciduous trees with broader tree canopies than either wetland or urbandominant reaches, they typically generate more leafy biomass in any given year.

\section{USGS research explored organic matter "above, around, and in" Fanno Creek.}

\section{Organic Matter Transport with Fine Sediment}

USGS scientists also assessed the organic matter (and carbon) contribution in the fine sediments along the floodplain and streambanks of Fanno Creek (fig. 4). Based on the carbon content of samples collected from the streambanks and measured rates of erosion and deposition, it was estimated that streambanks supplied between 50 and 120 t of organic matter annually during the study period. Generally, the organic matter stored in topsoil floodplain deposits was 2-5 times richer in carbon than that sampled directly from the subsoil of the streambanks. Comparatively, the streambanks supplied less organic matter to Fanno Creek than that measured from the foliage above.

Figure 3. Three-dimensional (3-D) view of tree canopy as represented by remotely sensed data (light detection and ranging [lidar]) near Durham City Park, Oregon. Lidar from Fusion software available at http://forsys.cfr.washington.edu/ fusion/fusionlatest.html.)

Deposition plates ( $30 \times 30$ centimeters) along the floodplain were routinely buried by sediment during high flow events.

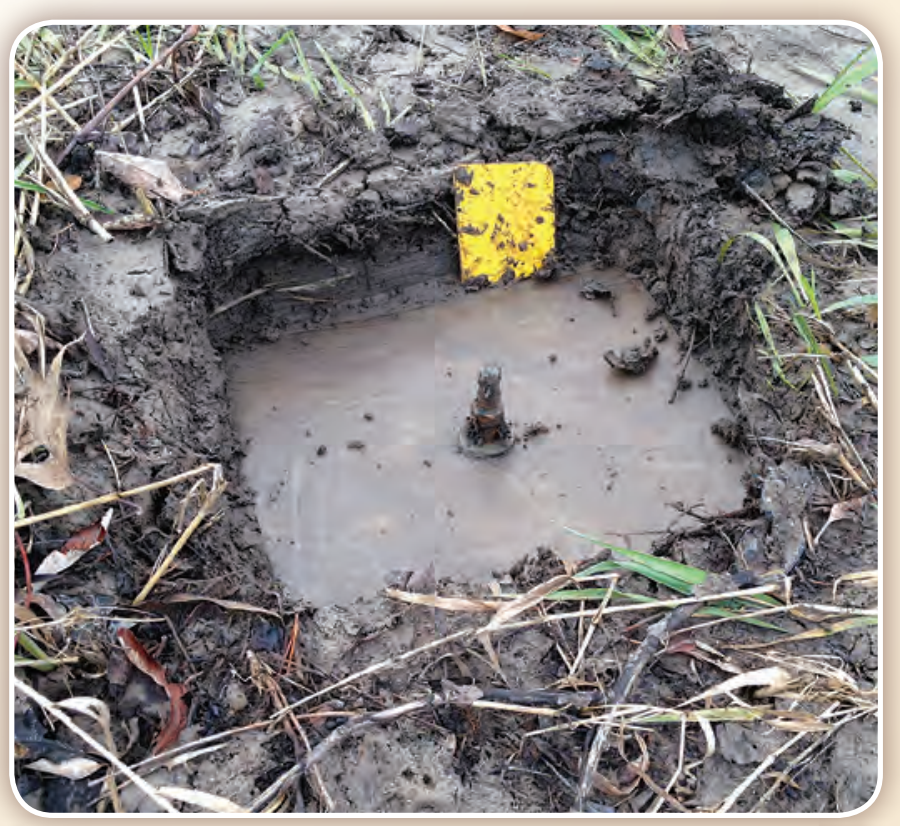




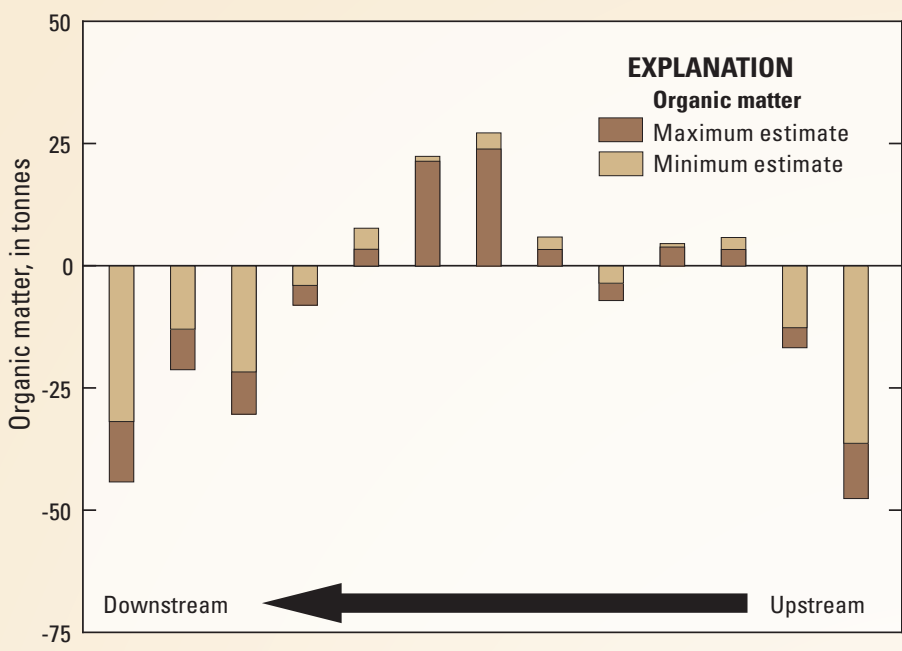

Figure 4. Organic matter contribution from fine sediments along Fanno Creek. Positive values indicate overall deposition or storage; negative values indicate erosion or export. Net deposition is greatest along the middle sections of Fanno Creek where wetlands have been restored

\section{Organic Matter as Instream Carbon}

In addition to estimating organic matter contributions from above and along Fanno Creek, USGS scientists also assessed the instream movement and characteristics of organic matter.
Using cutting-edge instream water-quality instruments (optical fluorescence sensors) and laboratory analyses (fluorescence spectroscopy and isotope chemistry), investigators estimated the amount and characteristics of dissolved, particulate, and total organic carbon in the stream. Each year, about $320 \mathrm{t}$ of organic carbon floats or flows through Fanno Creek, with about 70 percent of organic carbon dissolved in the water. The concentration of the dissolved organic carbon varies throughout the year, but generally amounts to at least 3-4 milligrams per liter $(\mathrm{mg} / \mathrm{L})$ during most of the year. The instream and laboratory analyses confirm previous findings that the carbon in the stream predominantly originates from terrestrial organic matter, such as from leaf litter or other surface-soil runoff.

\section{Mapping Erosion and Deposition}

Based on geomorphic maps of the floodplain (fig. 5), USGS scientists have identified where sediment is being eroded and deposited along Fanno Creek. The maps are useful resources for those who plan and restore wetlands or riparian areas. Approximately 70 percent of the creek's banks appeared highly erodible and resulted in 550-3,300 t of sediment being exported from Fanno Creek during the year-long study.

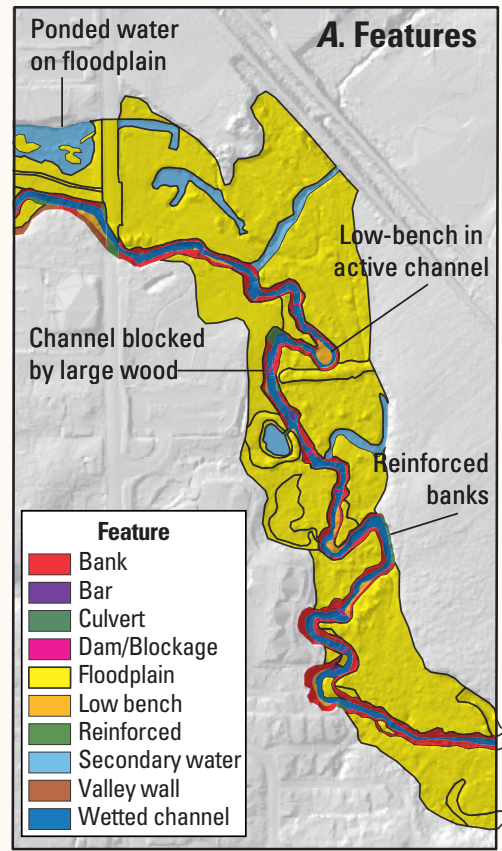

Base maps modified from Oregon Department of Geology and Miner Industries digital data, 1-meter resolution. UTM Zone 10, NAD83

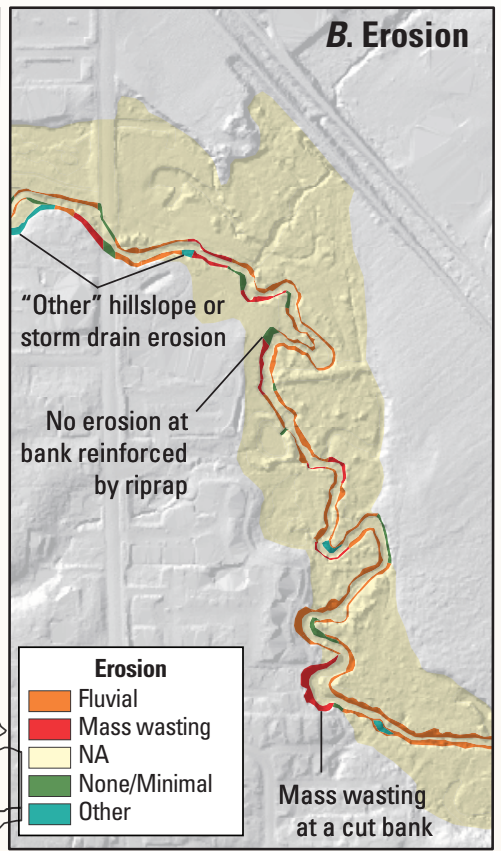
at a cut ban

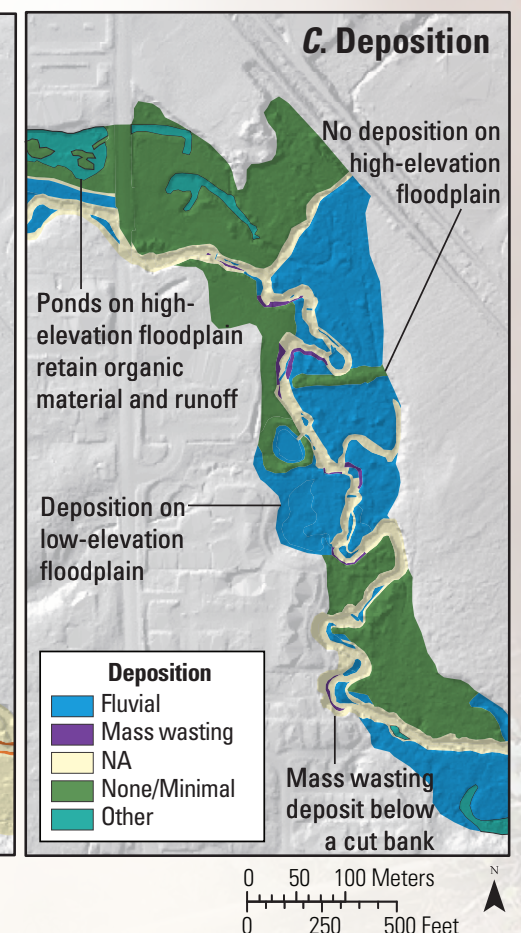

Figure 5. Examples of $(A)$ channel features, $(B)$ erosion areas, and $(C)$ deposition areas mapped by USGS scientists near Fanno Creek Park in Tigard, Oregon. 


\section{Organic Matter Transport Following the First Storm of Autumn}

In mid-October 2012, the first autumn storm swept across the Fanno Creek watershed. This first rain disturbed fine particulate materials that had been accumulating during spring and summer along the streambed and washed some materials into the stream from nearby storm systems and soils (fig. 6). Real-time water-quality monitoring equipment recorded the event (fig. 7). Due to the mobilization of this accumulated material, a large part of the annual supply of organic matter was transported during this storm, despite the fact that bigger storms occurred later in the year. Not only was the proportion of the organic matter greater during this first storm, but the transported material also was characteristically different than other storms. The organic matter showed more decomposition

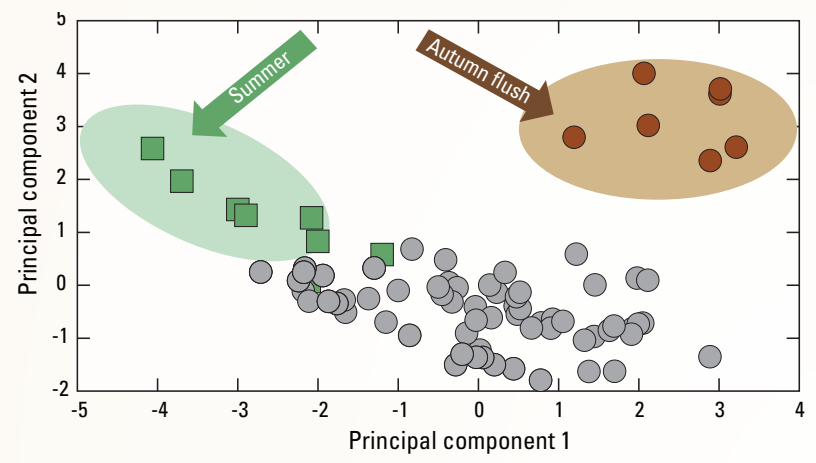

Figure 6. Statistical analysis of water-quality samples collected from Fanno Creek. The two sample periods (summer low flow and the first autumn storm) were characteristically different from other samples collected. through microbial activity, reinforcing the conclusion that easy-to-mobilize sediment and decomposing organic matter had accumulated in the streambed during the dry summer months. Downstream in the Tualatin River, this storm plume containing decomposing organic matter resulted in a measurable and significant decrease in dissolved oxygen, a condition that tends to occur with the first autumn storms in most years and is a potential water-quality concern for resource managers.

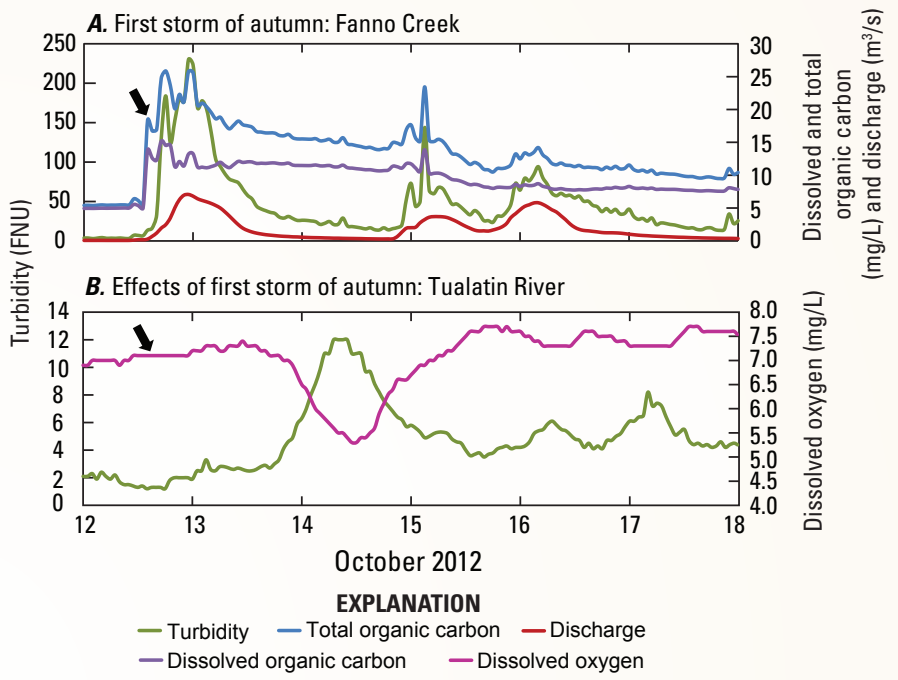

Figure 7. First autumn storm readings for Fanno Creek and downstream in the Tualatin River. (A) Turbidity, total organic carbon, discharge, and dissolved organic carbon patterns in Fanno Creek in October 2012. Arrow indicates the beginning of the storm. $(B)$ Dissolved oxygen and turbidity in the Tualatin River. The effects of the storm plume show up downstream about 1.5 days later.

\section{Implications for Watershed Management}

Fanno Creek flows through a heavily urbanized part of the Portland, Oregon area. As such, the watershed has many interested stakeholders, including municipalities, counties, utility providers, conservation groups, and private citizens. The health and safety of the creek has implications to more than just the aquatic life in the stream, but also to people who live and play along the creek. Therefore, it is useful to understand the critical water-quality issues in Fanno Creek and provide the maps, data, and insights necessary to assist resource managers to make decisions regarding management and restoration activities to maintain and enhance the stream environment.

\section{Full Results of the Study}

The results of the Fanno Creek study have been published in the Journal of Hydrology as a series of three articles. Figures presented in this fact sheet were modified from these articles.

Sobieszczyk, Steven, Keith, M.K., Rounds, S.A., and Goldman, J.H., 2014, Investigating organic matter in Fanno Creek, Oregon, part 1 of 3 - Estimating annual foliar biomass for a deciduous dominant urban riparian corridor: Journal of Hydrology, v. 519D, p. 30013009, http://dx.doi.org/10.1016/j.jhydrol.2014.06.054.

Keith, M.K., Sobieszczyk, Steven, Goldman, J.H., and Rounds, S.A., 2014, Investigating organic matter in Fanno Creek, Oregon, part 2 of 3 - Sources, sinks, and transport of organic matter with fine sediment: Journal of Hydrology, v. 519D, p. 3010-3027, http:// dx.doi.org/10.1016/j.jhydrol.2014.07.027.
Goldman, J.H., Rounds, S.A., Keith, M.K., and Sobieszczyk, Steven, 2014, Investigating organic matter in Fanno Creek, Oregon, part 3 of 3-Identifying and quantifying sources of organic matter to an urban stream: Journal of Hydrology, v. 519D, p. 3028-3041, http:// dx.doi.org/10.1016/j.jhydrol.2014.07.033.

Authors: Steven Sobieszczyk, Mackenzie K. Keith, Jami H. Goldman, and Stewart A. Rounds

\section{For information contact:}

Director, Oregon Water Science Center

U.S. Geological Survey

2130 SW 5th Ave., Portland, OR 97201

http://or.water.usgs.gov/ 